\title{
義肢装着者百余名を検診して
}

$\begin{array}{lllll}\text { 福岡県身体障害者更生指䆃所 } & \text { 香 } & \text { 月 } & \text { 正 } & \text { 紀 } \\ \text { 九州大学医学部整形外科教窒 } & \text { 道 } & \text { 免. } & \text { 土 } & \text { 人 }\end{array}$

\section{Results of Investigation about 108 Amputees with Prosthesis}

By

\section{Katsuki}

Fukuoka Prefectural Rehabilitations Center for Handicapped.

$\&$

\section{H. Doumen}

Department of Orthopedic Surgery, Kyushu University. (Direct. : Prof. T. Amako)

我々は, 本年 2 月 5 日より 5 日間, 福岡県各地で開 熦された義肢装着者に対する装着訓練に参加し, 切断 者の断端状況，装着して居る義肢及び装着状況につい て調查を行つた。

実施せられた地方は筑紫, 朝倉, 八女, 田川, 築上 の 5 ケ所で, 総計 108 名参集した。切断部位は下肢が $64 \%$ を占め, 大桹, 下腿, 上腕, 前腕の順である。年 龄は 15 才より 35 才までが多く, $69 \%$ 従つて義肢 装着年数も 5 年以上経験がある者が $82 \%$ \%り, 最高 は 51 年の経跧者であつた。今回参集した人々は義肢 装着して相当年数経ち, 社会人として働いて居る者が 大部分である訳である。

切断原因としては戦傷が多く, 上肢,下肢共に戦傷, 産業災害, 交通事故, 疾病の順で, 同じ傾何である。 断端実用長は上腕切断の中に肩関節離断を含めた為, $5 \mathrm{~cm}$ 以下の短断端が $33 \%$ あた外, 前腕, 大腿, 下 腿共に概して長い断端で, 其の形状は大腿, 下腿共に 円筒形, 円錐形の良好な者が多く70\%を占める。断 端筋萎縮度は大腿切断者に於て断端長を問題とせず, 根部，中央部，末端部に分けて測定したが，根部の $83.6 \%$ 亿対し末端部は $64.7 \%$ で萎縮高度となる。又, 下腿切断では下腿の委縮度 $74.6 \%$, 大腿の中央 周 径 $78.8 \%$ で，下腿のみならず，大腿まで大なる影響のあ る事を知るのである。切断後, 大腿では平均 13 年, 下腿で平均 19 年经過して居るので, この位が筋萎縮 の限界ではなからうか。切断してから 1 年以上義肢を 装着して居ない者は，上肢の $50 \%$ に反し下肢は $37 \%$ で, 下肢の方が早期淁着して居る。下肢切断者はそ
のまつでは起居移動に困難な為であろう。

大腿義肢の体重支持方法として, 断端支持, 坐骨支 持とに分けられる。しかし何れる単独で支持するので はなく，他比し奒部が支持に主に働くという区別に 過ぎない, 又肥満した人に多いが，何処といつて特に 支持する所がないという ののがある。便宜上全周芰持 としたら坐骨支持と同数で，断端支持は 1 名に過ぎな かつた。関節機構は滕関節固定, 足関節遊動が半数の $55 \%$ で最も多かつた。義胶の装着方法として, 肩バン ド, 腰バンドの件用が普遍的で $59 \%$ \%り, Suction は1名で未だ普欢して居るとは云い難い。下腿義肢で は足関節の遊動が僅かに $54 \%$ \%多かつたけれど, 何故 か固定も案外飞多かつた。義肢重量は製作所により差 異が大きかつたが, 平均の重量を求めると, 上腕 $1.2 \mathrm{~kg}$, 前腕 $0.5 \mathrm{~kg}$, 大腿 $3.2 \mathrm{~kg}$, 下腿 $1.9 \mathrm{~kg}$ で, 三好氏の調査 と大体一致する。大酿義肢は健側より若干短く製作す るのが通例である。实際に測定して見ると, 義肢長が $1 \sim 2 \mathrm{~cm}$ 短いものが大部分の $72 \%$ あるけれど, 中 には $5 \mathrm{~cm}$ も短い者や逆㼁肢が長い者も若下居た。

August Blencke は義肢長の短い為に, 切断者の狳 椎彎曲が起ると云い, 後藤氏も之れを肯定し, 未装着 者に脊椎側彎を見ずと云つて居る。斎藤氏は装着者 の $90.9 \%$ に見て居るし, 我々も亦 $89.7 \%$ 亿側彎を見 た。

下肢義肢の材料は大腿, 下腿義肢共に 1 名革製の外, 全部ニニーム製で木製は芫なかつた。

歩行距離は, 大腿切断も下腿切断も概してよく歩き, $2 \mathrm{~km}$ 以下が共に $23 \%$ \%あつたが, 最高は大腿切断で 
$49 \mathrm{~km}$, 南腿切断で 1 日中という篤買的な者も居た。階 段や圾道の昇降はさすがに大腿切断に於て不能 $3 \%$, 困難な者 $15 \%$ 存在する。杽降可能な者でも, 昇降共に 同程度という者 $59 \%$ ある外，降りる特の方が昇る時 より困難な者が約 2 倍多い。

発汗は上肢に少なく下肢が主であり，依つて義肢装 着の為めの皮濾損傷は上肢にはない。下肢は全身の体 重をかける関係からである。

義肢を常時装着して居る者は, 下腿, 大腿, 前腕, 上腕の順で，平均し上肢は $41 \%$ ，下肢は $77 \%$, 特々 装着するという上肢 $9 \%$ ，下肢 $3 \%$ を除いて何れも外 出, 労働特には全部装着して居る。第一次大戦後, 独 逸では上肢義肢の使用率 $10 \%$ ，水町氏によれば今次 大戦中 $50 \%$ であつたといらが，今回の成績がかくも 高率なのは装着訓練という特殊なケースである為であ ろう。

職業の中, 農業は前腕 $39 \%$, 以下上腕, 下腿, 大 腿の順で，農業は特に大腿切断者にとつて作業の性質 上適し難いのではあるまいか，それに反して洋裁，プ リント, 時計, ラジオ修理, 組立等の手先の技術的仕 事は反対に大腿 $41 \%$, 以下下腿, 前腕, 上腕の順で,
下肢切断者に圧倒的に多い。又切断時と現在の職業と を対比すれば，上肢切断の現職復帰は $28 \%$ ，之れに 対し下肢のそれは $49 \%$ そあり，転職は下肢の $25 \%$ に 比し $62 \%$ 占め, しかも上肢切断者の職種変更は愿々 である。之を要するに，上肢切断者に適当な職業のな い事に原因して居る。更生指導, 職業補導の拡充は勿 論, 社会問題として考らべき余地を残して居る。

二肢切断は 7 名, 6.9 で\%あつた。一肢切断に比べ受 ける精神的打撃は深刻で， $71 \%$ \%転職し，手先の技術 を職業として居る。

義肢装着者の希望事項は，義肢の耐久力の要望が最 も多からた。義肢の更新はまちまちであるが, 平均上 腕 5.1 年, 前腕 7.7 年, 大腿 6.1 年, 下腿 7.1 年であつ て，経済的な理由により義肢更新が思うに任せないの で，耐久力の要望も無理からぬ事である。

我々は義肢装着者つみを対称とし調査したが，初め ての試みであるので不充分の誹りは免れないと思う。 社会福祉法が制定せられて数年，四肢切断者に大なる 恩恵を与党て居る事を感じたのであるが，今後一層の 推進を希望するものである。

\section{会計報告}

